\title{
ВИЗНАЧЕННЯ КІЛЬКІСНОГО ВМІСТУ СУМИ ОРГАНІЧНИХ КИСЛОТ У НАСТОЙКАХ ІЗ СИРОВИНИ РОСЛИН РОДИН РОLYGONAСЕАЕ, ROSACEAE, ASTERACEAE
}

Вступ. Органічні кислоти відіграють важливу роль в організмі рослин і людини.

Мета дослідження - визначити кількісний вміст суми органічних кислот у серіях настойок з кореневищ з коренями щавлю кінського, родовика лікарського, коренів шипшини коричної і шипшини собачої, лопуха великого, лопуха малого та лопуха павутинистого, трави череди трироздільної.

Методи дослідження. Об'єктами дослідження були настойки, отримані з кореневищ з коренями щавлю кінського, родовика лікарського, коренів шипшини коричної і шипшини собачої, лопуха великого, лопуха малого та лопуха павутинистого, трави череди трироздільної, які одержано методом мацерації при кімнатній температурі та співвідношенні сировина/готова продукція 1:5, екстрагент - 50 \% спирт етиловий. Кількісний вміст суми органічних кислот визначали титриметричним методом (методика монографії ДФУ 2.0 “Шипшини плоди”, в перерахунку на яблучну кислоту).

Результати й обговорення. У серіях настойок із сировини поширених рослин родин Polygonaceae, Rosaceae, Asteraceae визначено кількісний вміст суми органічних кислот алкаліметричним методом, методику наведено у монографрії ДФУ 2.0 “Шипшини плоди”, встановлено їх граничні межі: для настойки 3 кореневищ з коренями щавлю кінського - не менше 3,5 мг/мл, настойки з кореневищ з коренями родовика лікарського - не менше 2,5 мг/мл, настойки з коренів шипшини коричної - не менше 2,1 мг/мл, настойки з коренів шипшини собачої - не менше 2,1 мг/мл, настойки з коренів лопуха великого - не менше 1,5 мг/мл, настойки з коренів лопуха малого - не менше 2,0 мг/мл, настойки з коренів лопуха павутинистого - не менше 1,8 мг/мл, настойки з трави череди трироздільної - не менше 1,0 мг/мл.

Висновки. Алкаліметричним методом у серіях настойок з кореневищ з коренями щавлю кінського, родовика лікарського, коренів шипшини коричної і шипшини собачої, лопуха великого, лопуха малого та лопуха павутинистого, трави череди трироздільної визначено кількісний вміст суми органічних кислот, встановлено граничні межі вмісту цих речовин. Отримані дані буде використано в подальших дослідженнях настойок із цих видів сировини.

КЛЮЧОВІ СЛОВА: настойка; щавель; родовик; шипшина; лопух; череда; органічні кислоти.

ВСТУП. В організмі рослин органічні кислоти беруть участь у метаболізмі нітрогену, засвоєнні фроссрору та фреруму, підвищують резистентність рослинного організму до впливу алюмінію [1], утворюють комплекси з важкими металами, що призводить до зменшення їх токсичності або взагалі детоксикації [2].

В організмі людини органічні кислоти відіграють важливу роль, оскільки стимулюють роботу слинних залоз, проявляють протизапальну, противиразкову, жовчогінну, антимікробну й антиоксидантну активність [3, 4]. Ця група біологічно активних речовин секретолітично впливає на роботу шлунково-кишкового тракту, стимулює перистальтику кишечника та створює сприятливі умови для нормалізації його мікрофрлори [5, 6], тому їх рекомендують як складову здорового харчування [7].

(с) Т. В. Опрошанська, О. П. Хворост, 2021.
Основне джерело органічних кислот - фррукти та овочі, але і лікарська рослинна сировина в значній кількості містить цю групу біологічно активних речовин $[8,9]$. Оскільки в медицині широко застосовують лікарську рослинну сировину або фрітозасоби на її основі, то визначення кількісного вмісту даних речовин і в сировині, і у фрітозасобах $є$ актуальним.

У Державній Фармакопеї України 2.0 (ДФУ 2.0) наявні монографії "Шипшини плоди”, “Гібіск”, "Калини плоди", в яких описано стандартизацію сировини за кількісним вмістом суми органічних кислот алкаліметричним титриметричним або потенціометричним методом [10-12].

Раніше ми вже визначили кількісний вміст суми органічних кислот у сировині поширених представників родин Polygonaceae (кореневище з коренями щавлю кінського), Rosaceae (кореневище 3 коренями родовика лікарського, корені 
шипшини коричної і шипшини собачої) та Asteracеае (корені лопуха великого, лопуха малого, лопуха павутинистого і трава череди трироздільної) $[13,14]$. Тому кількісне визначення цієї групи сполук у настойках з вищезгаданих видів сировини цілком доречне. Об'єктом нашого дослідження стали серії настойок із сировини рослин родин Polygonaceae, Rosaceae, Asteraceae.

Мета дослідження - визначити кількісний вміст суми органічних кислот у серіях настойок 3 кореневищ 3 коренями щавлю кінського, родовика лікарського, коренів шипшини коричної і шипшини собачої, лопуха великого, лопуха малого та лопуха павутинистого, трави череди трироздільної.
МЕТОДИ ДОСЛІДЖЕННЯ. ЯК об'єкТИ дослідження використовували настойки, отримані 3 кореневищ 3 коренями щ. кінського (серії 1.11.5), р. лікарського (серії 2.1-2.5), коренів ш. коричної (серії 3.1-3.5), ш. собачої (серії 4.1-4.5), л. великого (серії 5.1-5.5), л. малого (серії 6.16.5), л. павутинистого (серії 7.1-7.5) і трави ч. трироздільної (серії 8.1-8.5), які одержано методом мацерації при кімнатній температурі та співвідношенні сировина/готова продукція 1:5, екстрагент - 50 \% спирт етиловий [15]. Для отримання настойок застосовували сировину, яку заготовляли у 2019 р. (підземні органи - наприкінці вегетаційного періоду, а траву - у фразу бутонізації) (табл. 1).

Таблиця 1 - Термін заготівлі сировини деяких рослин родин Polygonaceae, Rosaceae, Asteraceae

\begin{tabular}{|c|c|c|c|}
\hline $\begin{array}{c}\text { Назва } \\
\text { сировини }\end{array}$ & Серія & $\begin{array}{c}\text { Термін } \\
\text { заготівлі }\end{array}$ & Місце заготівлі \\
\hline \multirow{5}{*}{$\begin{array}{l}\text { Кореневища } \\
3 \text { коренями } \\
\text { щ. кінського }\end{array}$} & 1.1 & 27.10 .2019 & Вінницька обл., Піщанський р-н, с. Трибусівка \\
\hline & 1.2 & 29.10 .2019 & Тернопільська обл., Гусятинський р-н, околиця смт Гусятина \\
\hline & 1.3 & 23.10 .2019 & Харківська обл., Чугуївський р-н, с. Велика Бабка \\
\hline & 1.4 & 24.10 .2019 & Полтавська обл., Диканський р-н, с. Михайлівка \\
\hline & 1.5 & 24.10 .2019 & Хмельницька обл., Летичівський р-н, с. Антоновка \\
\hline \multirow{3}{*}{$\begin{array}{l}\text { Кореневища } \\
3 \text { коренями } \\
\text { р. лікарського }\end{array}$} & 2.2 & 25.09 .2019 & $\begin{array}{l}\text { Хмельницька обл., Городоцький р-н, присадибні ділянки } \\
\text { с. Яромирки }\end{array}$ \\
\hline & 2.3 & 27.09 .2019 & Присадибні ділянки м. Вінниці \\
\hline & 2.4 & 26.09 .2019 & $\begin{array}{l}\text { Дослідні ділянки Національного ботанічного саду } \\
\text { ім. М. М. Гришка НАН України в м. Києві }\end{array}$ \\
\hline \multirow{3}{*}{$\begin{array}{l}\text { Корені } \\
\text { ш. коричної }\end{array}$} & 3.3 & 26.10 .2019 & Харківська обл., Чугуївський р-н, с. Кам'яна Яруга \\
\hline & 3.4 & 31.10 .2019 & Львівська обл., Жовківський р-н, смт Куликів \\
\hline & 3.5 & 27.10 .2019 & Вінницька обл., Ямпільський р-н, с. Довжок \\
\hline \multirow{5}{*}{$\begin{array}{l}\text { Корені } \\
\text { ш. собачої }\end{array}$} & 4.1 & 22.10 .2019 & Вінницька обл., Піщанський р-н, с. Трибусівка \\
\hline & 4.2 & 10.11 .2019 & Тернопільська обл., Гусятинський р-н, околиця смт Гусятина \\
\hline & 4.3 & 26.10 .2019 & Харківська обл., Чугуївський р-н, с. Кам'яна Яруга \\
\hline & 4.4 & 31.10 .2019 & Львівська обл., Жовківський р-н, смт Куликів \\
\hline & 4.5 & 27.10 .2019 & Вінницька обл., Ямпільський р-н, с. Довжок \\
\hline \multirow{2}{*}{$\begin{array}{l}\text { Корені } \\
\text { л. великого }\end{array}$} & 5.1 & 22.10 .2019 & Вінницька обл., Піщанський р-н, с. Трибусівка \\
\hline & 5.2 & 25.10 .2019 & Тернопільська обл., Гусятинський р-н, околиця смт Гусятина \\
\hline $\begin{array}{l}\text { Корені } \\
\text { л. малого }\end{array}$ & 6.5 & 23.10 .2019 & Вінницька обл., Томашпільський р-н, с. Вила \\
\hline \multirow{5}{*}{$\begin{array}{l}\text { Корені } \\
\text { л. павутинистого }\end{array}$} & 7.1 & 22.10 .2019 & Вінницька обл., Піщанський р-н, с. Трибусівка \\
\hline & 7.2 & 25.10 .2019 & Тернопільська обл., Гусятинський р-н, околиця смт Гусятина \\
\hline & 7.3 & 26.10 .2019 & Харківська обл., Чугуївський р-н, с. Кам'яна Яруга \\
\hline & 7.4 & 22.10 .2019 & Львівська обл., Жовківський р-н, смт Куликів \\
\hline & 7.5 & 23.10.2019 & Вінницька обл., Томашпільський р-н, с. Вила \\
\hline \multirow{5}{*}{$\begin{array}{l}\text { Трава } \\
\text { ч. трироздільної }\end{array}$} & 8.1 & 13.08.2019 & Вінницька обл., Піщанський р-н, с. Трибусівка \\
\hline & 8.2 & 18.08.2019 & Тернопільська обл., Гусятинський р-н, околиця смт Гусятина \\
\hline & 8.3 & 15.08 .2019 & Харківська обл., Чугуївський р-н, с. Кам'яна Яруга \\
\hline & 8.4 & 12.08.2019 & Вінницька обл., Ямпільський р-н, с. Качківка \\
\hline & 8.5 & 14.08.2019 & Харківська обл., Чугуївський р-н, с. Велика Бабка \\
\hline
\end{tabular}


Кількісний вміст суми органічних кислот визначали титриметричним методом (методика монограсрії ДФУ 2.0 “Шипшини плоди”, в перерахунку на яблучну кислоту) [10].

РЕЗУЛЬТАТИЙОБГОВОРЕННЯ. РЕЗУЛЬТаТИ визначення кількісного вмісту суми органічних кислот у різних серіях настойок із сировини деяких рослин родин Polygonaceae, Rosaceae, Asteraceae наведено в таблиці 2.

3 таблиці 2 видно, що найвищий кількісний вміст суми органічних кислот притаманний настойці 3 кореневищ 3 коренями щ. кінського та коливається від $(3,91 \pm 0,19)$ мг/мл (серія 1.4) до $(4,26 \pm 0,18)$ мг/мл (серія 1.1).

У настойці з кореневищ з коренями р. лікарського вміст суми органічних кислот коливався незначно, найнижчий вміст визначено в серії $2.5((2,58 \pm 0,11)$ мг/мл), а найвищий - у серії $2.2((2,98 \pm 0,13)$ мг/мл). У настойках з коренів ш. коричної і ш. собачої вміст суми органічних кислот коливався також незначно, був дещо більшим у настойці з коренів ш. коричної і становив у настойках з обох видів сировини не менше 2,1 мг/мл.

Що стосується настойок із сировини трьох видів лопуха, то найвищий вміст цієї групи сполук спостерігали в настойці 3 коренів л. малого $((2,31 \pm 0,11)$ мг/мл, серія 6.2), найнижчий - у настойці з коренів л. великого $((1,64 \pm 0,07)$ мг/мл, серія 5.5). У настойці з трави ч. трироздільної вміст суми органічних кислот коливався від $(1,10 \pm 0,05)$ мг/мл (серія 8.2) до $(1,18 \pm 0,06)$ мг/мл (cepiï 8.1 i 8.3).

Таблиця 2 - Визначення кількісного вмісту суми органічних кислот у настойках із сировини деяких рослин родин Polygonaceae, Rosaceae, Asteraceae (n=5, в розрахунку на 1 мл настойки)

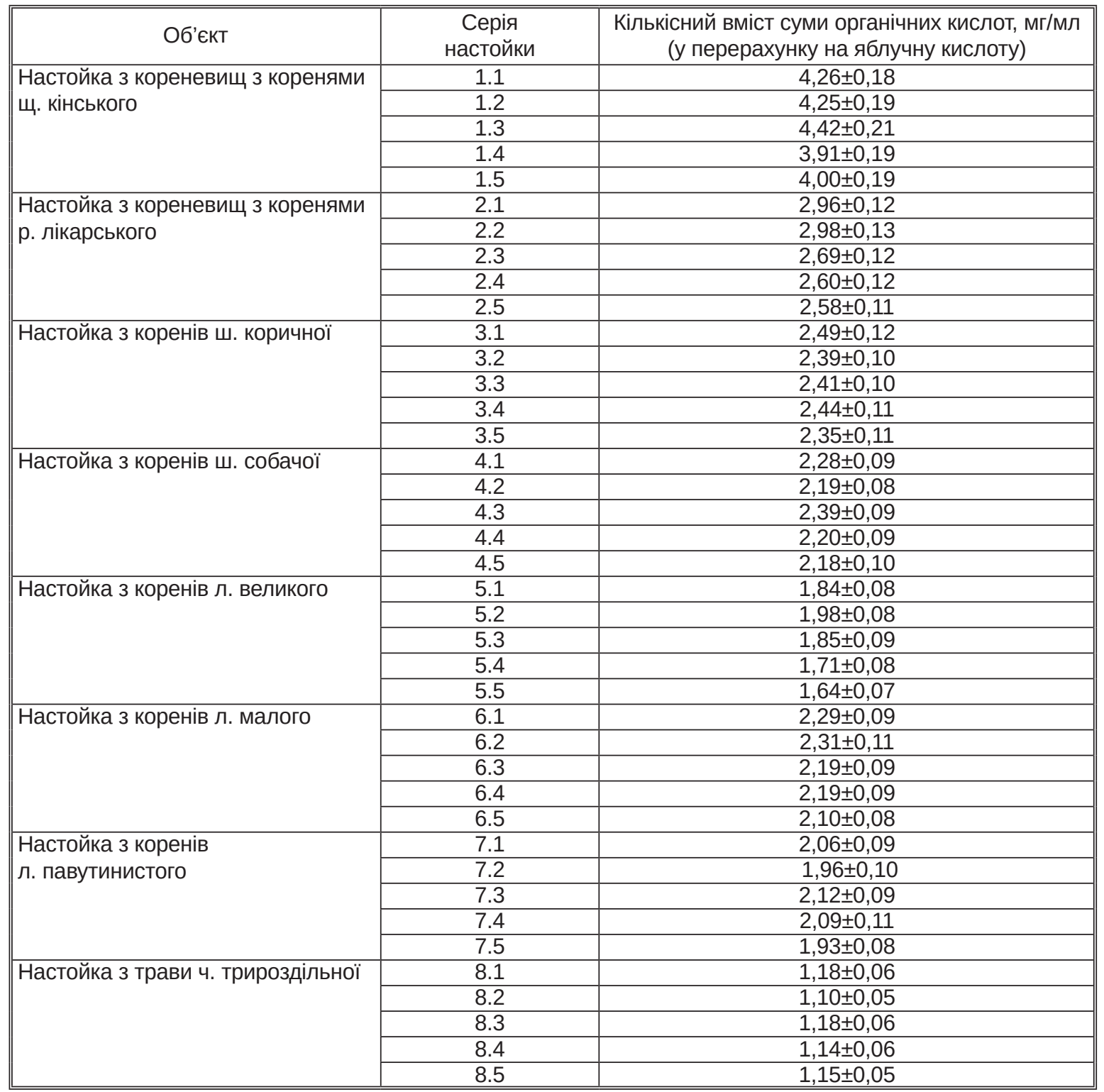


Отже, в серіях настойок із сировини поширених рослин родин Polygonaceae, Rosaceae, Asteraceae визначено кількісний вміст суми органічних кислот алкаліметричним методом (методику наведено у монограсрії ДФУ 2.0 “Шипшини плоди"), встановлено їх граничні межі: для настойки з кореневищ з коренями щ. кінського не менше 3,5 мг/мл, настойки 3 кореневищ 3 коренями р. лікарського - не менше 2,5 мг/мл, настойки 3 коренів ш. коричної - не менше 2,1 мг/мл, настойки 3 коренів ш. собачої - не менше 2,1 мг/мл, настойки 3 коренів л. великого - не менше 1,5 мг/мл, настойки 3 коренів л. малого - не менше 2,0 мг/мл, настойки 3 коренів л. павутинистого - не менше 1,8 мг/мл, настойки з трави ч. трироздільної - не менше $1,0 \mathrm{мг/мл.}$

ВИСНОВКИ. Алкаліметричним методом у серіях настойок з кореневищ 3 коренями щ. кінського, р. лікарського, коренів ш. коричної і ш. собачої, л. великого, л. малого та л. павутинистого, трави ч. трироздільної визначено кількісний вміст суми органічних кислот, встановлено граничні межі вмісту цих речовин: для настойки з кореневищ з коренями щ. кінського - не менше 3,5 мг/мл, настойки 3 кореневищ 3 коренями р. лікарського - не менше 2,5 мг/мл, настойки 3 коренів ш. коричної - не менше 2,1 мг/мл, настойки $з$ коренів ш. собачої - не менше 2,1 мг/мл, настойки з коренів л. великого - не менше 1,5 мг/мл, настойки з коренів л. малого не менше 2,0 мг/мл, настойки 3 коренів л. павутинистого - не менше 1,8 мг/мл, настойки 3 трави ч. трироздільної - не менше 1,0 мг/мл. Отримані дані буде використано в подальших дослідженнях настойок із цих видів сировини.

Конфрлікт інтересів. Автори підтверджують відсутність консрлікту інтересів у цій публікації.

\section{СПИСОК ЛІТЕРАТУРИ}

1. Wang J. Roles of organic acid metabolism in plant adaptation to nutrient deficiency and aluminum toxicity stress. / J. Wang, Q. Shen // Ying Yong Sheng Tai Xue Bao. - 2006. - 17 (11). - P. 2210-2216.

2. Liujie Wu. Organic acid excretion from roots: a plant mechanism for enhancing phosphorus acquisition, enhancing aluminum tolerance, and recruiting beneficial rhizobacteria / Wu Liujie, Kobayashi Yuriko, Wasaki Jun \& Koyama Hiroyuki // Soil Science and Plant Nutrition. 2018. - 64 (6). - P. 697-704. DOI: 10.1080/00380768. 2018.1537093

3. Органические кислоты синюхи голубой / Г. Ю. Шестакова, А. А. Гудкова, А. С. Чистякова, В. А. Агафонов // Бюлл. Государственного Никитского ботанического сада. - 2021. - № 138. - С. 85-91.

4. Санькова М. В. Фитохимическое определение суммы органических кислот в листьях крыжовника отклоненного / М. В. Санькова, О. В. Нестерова // Мед.-фрармац. журн "Пульс". - 2020. - 22, № 3. C. 72-76.

5. Analysis of organic acids of tricarboxylic acid cycle in plants using GC-MS, and system modeling / Kumar Vinod, Sharma Anket, Bhardwaj Renu, Kumar Thukral Ashwani // Journal of Analytical Science and Technology. 2017. - 8. - P. 20.

6. Simultaneous determination of 14 organic acids in Shenfu injection by hydrophilic interaction chromatography-tandem mass spectrometry / Yao Liu, Na Zhang, ShePo Shi [et al.] // Zhongguo Zhong Yao Za Zhi. 2016. - 41 (18). - P. 3342-3348.

7. Krzymińska A. Content of phenolic compounds and organic acids in the flowers of selected Tulipa gesneriana cultivars / A. Krzymińska, M. Gasecka, Z. Magdziak // Molecules (Basel, Switzerland). - 2020. 25 (23). - P. 5627. DOI: https://doi.org/10.3390/molecules 25235627

8. Optimization of conditions for organic acid extraction from edible plant material as applied to radish sprouts / Joanna Chlopicka, Justyna DobrowolskaIwanek, Michal Wozniakiewicz, Pawel Zagrodzki // Food Anal. Method. - 2014. - 7 (6). - P.1323-1327.

9. Regulation of phytochemicals in fruits and berries by environmental variation-Sugars and organic acids / J. Zheng, C. Huang, B. Yang [et al.] // Journal of Food Biochemistry. - 2019. - 43 (6). - P. 12642. DOI: https:// doi.org/10.1111/jfbc.12642

10. Державна Фармакопея України : в 3 т. / Державне підприємство "Український науковий фрармакопейний центр якості лікарських засобів". - 2-ге вид. Харків : Державне підприємство "Український науковий фрармакопейний центр якості лікарських засобів", 2014. - T. 3. - 732 c.

11. Державна Фармакопея України / Державне підприємство “Український науковий фрармакопейний центр якості лікарських засобів". - 2-ге вид. - Допов. 1. - Харків : Державне підприємство “Український науковий фрармакопейний центр якості лікарських засобів", 2016. - 360 с.

12. Державна Фармакопея України / Державне підприємство "Український науковий фрармакопейний центр якості лікарських засобів". - 2-ге вид. - Допов. 4. - Харків : Державне підприємство "Український науковий срармакопейний центр якості лікарських засобів", 2020. - 600 с. 
13. Опрошанська Т. В. Кількісний вміст суми органічних кислот в серіях сировини деяких представників родин Polygonaceae, Rosaceae та Asteraceae / Т. В. Опрошанська, О. П. Хворост, В. В. Кудря // Мед. та клініч. хімія. - 2020. - 22, № 3 (85). - С. 81-86.

14. Опрошанська Т. В. Потенціометричне визначення кількісного вмісту суми органічних кислот у лікарській рослинній сировині / Т. В. Опрошанська,
О. П. Хворост // Вісн. фрармації. - 2021. - № 1 (101). C. 11-17.

15. Державна Фармакопея України : в 3 т. / Державне підприємство "Український науковий фрармакопейний центр якості лікарських засобів". - 2-ге вид. Харків : Державне підприємство "Український науковий фрармакопейний центр якості лікарських засобів", 2015. - T. 1. - 1128 c.

\section{REFERENCES}

1. Wang, J., \& Shen, Q. (2006). Roles of organic acid metabolism in plant adaptation to nutrient deficiency and aluminum toxicity stress. Ying Yong Sheng Tai Xue Bao, 17 (11), 2210.

2. Liujie Wu, Yuriko Kobayashi, Jun Wasaki \& Hiroyuki Koyama. (2018). Organic acid excretion from roots: a plant mechanism for enhancing phosphorus acquisition, enhancing aluminum tolerance, and recruiting beneficial rhizobacteria. Soil Science and Plant Nutrition, 64 (6), 697. DOI: 10.1080/00380768.2018.1537093

3. Shestakova G.Yu., Gudkova, A.A., Chistyakova, A.S., \& Agafonov, V.A. (2021). Organic acids of cyanosis blue. Bulletin of State Nikitsky Botanical Garden 138, 85. DOI: 10.36305/0513-1634-2021-138-85-91 [in Russian].

4. Sankova, M.V., \& Nesterova, O.V. (2020). Phytochemical determination of the amount of organic acids in rejected gooseberry leaves. Med. and Pharmaceutical Journal "Pulse", 22 (3), 72. DOI: 10.26787/nydha-26866838-2020-22-3-72-76 [in Russian].

5. Kumar Vinod, Sharma Anket, Bhardwaj Renu \& Kumar Thukral Ashwani (2017). Analysis of organic acids of tricarboxylic acid cycle in plants using GC-MS, and system modeling. Journal of Analytical Science and Technology, 8, 20.

6. Yao Liu, Na Zhang, ShePo Shi Qingqing Song, Jielan Li, Yuelin Song \& Peng-Fei Tu. (2018). Simultaneous determination of 14 organic acids in Shenfu injection by hydrophilic interaction chromatography-tandem mass spectrometry. Zhongguo Zhong Yao Za Zhi, 41 (18), 3342-48.

7. KrzymińskaA, Gąsecka, M, \& Magdziak Z. (2020). Content of phenolic compounds and organic acids in the flowers of selected Tulipa gesneriana cultivars. Molecules (Basel, Switzerland), 25 (23), 5627. DOI: https://doi. org/10.3390/molecules25235627
8. Joanna Chlopicka, Justyna Dobrowolska-Iwanek, Michal Wozniakiewicz \& Pawel Zagrodzki. (2014). Optimization of conditions for organic acid extraction from edible plant material as applied to radish sprouts. Food Anal. Method., 7 (6), 1323-1327.

9. Zheng, J., Huang, C., Yang, B., Kallio, H., Liu, P., \& Ou, S. (2019). Regulation of phytochemicals in fruits and berries by environmental variation-Sugars and organic acids. Journal of Food Biochemistry, 43 (6), e12642. DOI: https://doi.org/10.1111/jfbc.12642

10. (2014). State Pharmacopoeia of Ukraine. $2^{\text {nd }}$ edition. Vol. 3. Kharkiv: Derzhavne pidpryiemstvo "Ukrayinskyi naukovyi farmakopeinyi tsentr yakosti likarskykh zasobiv" [in Ukrainian].

11. (2016). [State Pharmacopoeia of Ukraine. $2^{\text {nd }}$ edition. Appendix 1]. Kharkiv: Derzhavne pidpryiemstvo "Ukrayinskyi naukovyi farmakopeinyi tsentr yakosti likarskykh zasobiv" [in Ukrainian].

12. (2020). State Pharmacopoeia of Ukraine. $2^{\text {nd }}$ edition. Appendix 4]. Kharkiv: Derzhavne pidpryiemstvo "Ukrayinskyi naukovyi farmakopeinyi tsentr yakosti likarskykh zasobiv" [in Ukrainian].

13. Oproshanska, T.V., Khvorost, O.P., \& Kudria, V.V. (2020). Quantitative content of the sum of organic acids in the series of raw materials of some members of the families Polygonaceae, Rosaceae and Asteraceae. Medychna ta klinichna khimiia, 22 (3), 81. DOI: https://doi. org/10.11603/mcch.2410-681X.2020.v.i3.11543 [in Ukrainian].

14. Oproshanska, T.V., \& Khvorost, O.P. Potentiometric determination of the quantitative content of the sum of organic acids in medicinal plant raw materials. Bulletin of Pharmacyi, 1:101, 11. DOI: https://doi.org/10.24959/ nphj.21.42 [in Ukrainian].

15. (2015). State Pharmacopoeia of Ukraine. $2^{\text {nd }}$ edition. Vol. 1]. Kharkiv: Derzhavne pidpryiemstvo "Ukrayinskyi naukovyi farmakopeinyi tsentr yakosti likarskykh zasobiv" [in Ukrainian]. 


\section{DETERMINATION OF QUANTITATIVE CONTENT OF THE AMOUNT OF ORGANIC ACIDS IN TINCTURES FROM RAW MATERIALS OF PLANTS OF THE FAMILIES POLYGONACEAE, ROSACEAE, ASTERACEAE}

\section{Summary}

Introduction. Organic acids play an important role in the body of plants and humans.

The aim of the study - to determine the quantitative content of the amount of organic acids in a series of tinctures of rhizomes with roots of Rumex confertus, Sanguisorba officinalis, roots of Rosa majalis, Rosa canina, Arctium lappa, Arctium minus, Arctium tomentosum and herbs of Bidens tripartita.

Research Methods. Objects of study are tinctures from different series of rhizomes with roots of Rumex confertus, Sanguisorba officinalis, roots of Rosa majalis, Rosa canina, Arctium lappa, Arctium minus, Arctium tomentosum and herbs of Bidens tripartita, which were obtained by maceration at room temperature and ratio plant raw materials/finished products 1:5, extractant $50 \%$ ethanol. Quantitative content of the amount of organic acids was determined by titrimetric method (method of monograph SPhU 2.0 "Rose hips", in terms of malic acid).

Results and Discussion. The quantitative content of the amount of organic acids was determined in some series of tinctures from plant raw materials of some plants of the families Polygonaceae, Rosaceae, Asteraceae by the alkalimetric method which is given in the monograph of SPhU 2.0 "Rose hips". It was determined the limits of them which was respectively not less than $3.5 \mathrm{mg} / \mathrm{ml}$ for the tincture of rhizomes with roots of Rumex confertus, $2,5 \mathrm{mg} / \mathrm{ml}$ for the tincture of rhizomes with roots of Sanguisorba officinalis, on $2.1 \mathrm{mg} / \mathrm{ml}$ for the tincture of roots of Rosa majalis and Rosa canina, $1.5 \mathrm{mg} / \mathrm{ml}$ for the tincture of the roots of Arctium lappa, $2.0 \mathrm{mg} / \mathrm{ml}$ for the tincture of the roots of Arctium minus, $1.8 \mathrm{mg} / \mathrm{ml}$ for the tincture of the roots of Arctium tomentosum, $1,0 \mathrm{mg} / \mathrm{ml}$ for tincture of herbs of Bidens tripartita.

Conclusions. The quantitative content of the amount of organic acids was determined by alkalimetric method in series of tinctures of rhizomes with roots of Rumex confertus, Sanguisorba officinalis, roots of Rosa majalis, Rosa canina, Arctium lappa, Arctium minus, Arctium tomentosum and herbs of Bidens tripartita. The obtained data will be used in further studies of tinctures from these types of plant raw materials.

KEY WORDS: tincture; rumex; sanguisorba; rose hip; arctium; bidens; organic acids.

Отримано 29.11.21

Адреса для листування: Т. В. Опрошанська, вул. Гв. Широнінців, 39б, кв. 124, Харків, 61170, Україна, e-mail: arctium55@ukr.net. 